\title{
Sensitization to storage proteins in peanut and hazelnut is associated with higher levels of inflammatory markers in asthma
}

\author{
Jennifer Johnson ${ }^{1}$, Andrei Malinovschi ${ }^{2}$, Jonas Lidholm³ ${ }^{3}$, Carl Johan Petersson ${ }^{3 *} \mathbb{C}$, Lennart Nordvall ${ }^{1}$, \\ Christer Janson ${ }^{4}$, Kjell Alving ${ }^{1}$ and Magnus P. Borres ${ }^{1,3}$
}

\begin{abstract}
Background: Sensitization to peanuts and hazelnuts is common among young asthmatics and can be primary or a result of cross-reactivity. Sensitization as a result of cross-reactivity to birch pollen is typically associated to tolerance or mild and local symptoms upon intake of peanut or hazelnut.

Aim: The aim of this study was to investigate relationships between IgE antibody responses against peanut and hazelnut components, airway and systemic inflammation markers, lung function parameters and reported food hypersensitivity in a cohort of asthmatic children and young adults.
\end{abstract}

Methods: A population of 408 asthmatic individuals aged 10-35 years were investigated. Information on hypersensitivity symptoms upon intake of peanut or hazelnut were recorded in a standardized questionnaire. Fraction of exhaled nitric oxide (FeNO), blood eosinophil count (B-Eos), spirometry, methacholine challenge outcome and IgE antibodies to peanut and hazelnut allergens were measured by standard clinical and laboratory methods.

Results: Subjects sensitized to any of the peanut (Ara h 1,2 or 3) or hazelnut (Cor a 9 or 14) storage proteins were significantly younger (17.6 vs 21.2 years), had higher levels of FeNO (23.2 vs 16.7 ppb) and B-Eos (340 vs 170 cells/ $\mathrm{mcl}$ ) than those displaying only pollen-related cross-reactive sensitization. Levels of FeNO correlated with levels of lgE to storage proteins in children, but not in adults. Levels of B-Eos correlated with levels of IgE to all allergen components investigated in children, but only to levels of lgE to storage proteins in adults. Anaphylaxis and skin reactions upon intake of peanuts or hazelnuts were more often reported among subjects sensitized to the respective storage proteins than among those with only pollen-related cross-reactive sensitization. As compared to peanut, hazelnut was more often reported to cause gastrointestinal symptoms and less often oral cavity symptoms.

Conclusions: Sensitization to peanut and hazelnut storage proteins was associated with higher levels of inflammation markers and food hypersensitivity symptoms in this population of subjects with asthma.

Keywords: Asthma, Allergy, Specific IgE, Molecular allergy diagnostics, Food allergen components, Hazel nut, Peanut, Sensitization

${ }^{*}$ Correspondence: carljohan.petersson@telia.com

${ }^{3}$ Thermo Fisher Scientific, Uppsala, Sweden

Full list of author information is available at the end of the article

\section{Background}

Sensitization to a particular allergen source can be either primary or secondary, the latter occurring as a result of cross-reactivity to proteins from a different allergen source but with similar molecular structures. The major peanut allergens are the storage proteins Ara h 1, Ara h 2 and Ara h 3 [1-4]. IgE against Ara h 2 is the most

(c) The Author(s) 2020. This article is licensed under a Creative Commons Attribution 4.0 International License, which permits use, sharing, adaptation, distribution and reproduction in any medium or format, as long as you give appropriate credit to the original author(s) and the source, provide a link to the Creative Commons licence, and indicate if changes were made. The images or other third party material in this article are included in the article's Creative Commons licence, unless indicated otherwise in a credit line to the material. If material is not included in the article's Creative Commons licence and your intended use is not permitted by statutory regulation or exceeds the permitted use, you will need to obtain permission directly from the copyright holder. To view a copy of this licence, visit http://creativeco mmons.org/licenses/by/4.0/. The Creative Commons Public Domain Dedication waiver (http://creativecommons.org/publicdomain/ zero/1.0/) applies to the data made available in this article, unless otherwise stated in a credit line to the data. 
important predictor of clinical peanut allergy [2-9] and may be used to reduce the need for food challenges. IgE recognition of Ara h 8 occurs as a result of cross reactivity with the birch pollen allergen Bet $\mathrm{v} 1$ or the corresponding protein from related tree species. Due to the low content of Ara $\mathrm{h} 8$ in peanuts, sensitization to Ara $\mathrm{h} 8$ is not always detectable using whole peanut extract [10]. Isolated Ara h 8 sensitization is almost always associated with peanut tolerance or mild symptoms upon peanut intake [11].

Patients with birch pollen-associated hazelnut allergy are sensitized to Cor a 1 and usually present with mild oral symptoms [12, 13]. IgE against the storage proteins Cor a 9 and Cor a 14, both major hazelnut allergens, can be used as markers for primary hazelnut sensitization and risk of more severe reactions $[14,15]$.

We have previously shown that sensitization to hazelnut and peanut is common among young asthmatics in Sweden [16]. Of the subjects included in this cohort, 54\% were sensitized to hazelnut, $25 \%$ to peanut and $56 \%$ to birch pollen. Food allergen sensitization affects both local and systemic markers of inflammation in asthma $[17,18]$. Patients with both asthma and food allergy have more severe asthma, with an increased risk of exacerbations, a higher rate of corticosteroid use and more frequent hospitalization, than asthmatics without food allergy [19-23]. Furthermore, asthma is a risk factor for fatal anaphylactic reactions to foods [24].

The aim of this study was to investigate molecular patterns of IgE antibody responses among young asthmatic individuals sensitized to peanut and hazelnut and to investigate correlations to levels of inflammation markers, exhaled NO, spirometry results, methacholine challenge and reported hypersensitivity reactions to these foods.

\section{Methods}

\section{Study population}

Within the framework of a Swedish academy-industry collaboration, the MIDAS project, a total of 408 children and young adults $(10-\leq 18$ respectively $>18-35$ years of age) with physician-diagnosed asthma were recruited in Uppsala, Sweden [16, 17]. All subjects were on daily treatment with inhaled corticosteroids (ICS) and/or oral leukotriene receptor antagonists (LTRA) during at least 3 months of the year before study entry.

\section{IgE antibody measurements}

All IgE analyses were performed by ImmunoCAP (Thermo Fisher Scientific, Uppsala, Sweden). IgE antibody concentrations $\geq 0.35 \mathrm{kU}_{\mathrm{A}} / \mathrm{L}$ were regarded as positive in this study. Peanut and hazelnut sensitization were defined as a positive IgE antibody test to any of whole peanut extract, Ara h 1, Ara h 2, Ara h 3 or Ara h 8 and to any of whole hazelnut extract, Cor a 1, Cor a 9 or Cor a 14 respectively.

Atopy was defined as a positive IgE test to a positive result from the multi-allergen food test $\mathrm{fx}(5)$ (egg, cow's milk, cod fish, wheat, peanut, soy, hazelnut and shrimp) and/or a positive result from the multi-allergen test Phadiatop (grass, tree and weed pollen and animal, mite and mold). Fx(5) and Phadiatop were delivered by Thermo Fisher Scientific, Uppsala, Sweden,

\section{Measurement of airway and systemic inflammation markers and lung function}

The fraction of exhaled nitric oxide (FeNO; airway inflammation marker) was measured with a chemiluminescence analyzer (NIOX Flex, Aerocrine $A B$, Solna, Sweden). Eosinophil blood count (B-Eos; systemic inflammation marker) was measured with a routine method (Cell-Dyn Sapphire, Abbott, Illinois, USA). Forced expiratory volume during one second (FEV1) was recorded with a MasterScope spirometer (Erich Jaeger, Wurzburg, Germany) and was used as a measure of pulmonary function. The methacholine provocative dose causing a fall of FEV1 by $20 \%$ (PD20) was determined with the Aerosol Provocation System (Viasys Healthcare $\mathrm{GmbH}$, Germany). Measurements were done in accordance with standardized routines and guidelines [25-27] and have been described in detail elsewhere [16, 17, 28]. Blood samples used for ECP analysis (Eosinophil Cationic Protein, systemic inflammation marker) were collected in SST tubes and left for $60 \mathrm{~min}$ at room temperature. Thereafter, they were centrifuged at $3000 \mathrm{rpm}$ for $15 \mathrm{~min}$ and stored in Sarstedt sample tubes at $-20^{\circ} \mathrm{C}$. The samples were analysed with the ImmunoCAP ECP assay. An S-ECP level $\geq 20 \mu \mathrm{g} / \mathrm{L}$ was defined as elevated.

\section{Asthma medication}

The subjects' use of ICS, combination ICS/long-acting beta-agonists (LABA) and/or LTRA during the past 3 months was recorded in the interview. The prescribed daily dose of ICS was collected from the subjects' medical records [16].

\section{Perceived food hypersensitivity symptoms}

Subjects were asked to report any history of hypersensitivity reactions upon intake of peanut and/or hazelnut during the last year. Symptoms were grouped according to the organ systems affected: the lower airways (asthma), the upper airways (rhinitis, conjunctivitis), the oral cavity (oral allergy syndrome), the skin (atopic dermatitis, urticarial, angioedema), the gastrointestinal tract (nausea, vomiting, stomach pain, diarrhea) and anaphylaxis 
(self-reported) [16]. Interviews were conducted by an allergy nurse, with the use of a structured questionnaire [16].

\section{Statistical analysis}

Categorical variables were described using percentages and differences between groups were studied with the $\mathrm{X} 2$ test. Normally distributed continuous variables were described using means and standard deviations and the $t$ test was used to compare means. If continuous variables had a distribution skewed to the right (e.g. FeNO), a geometric mean with a $95 \%$ confidence interval was used for descriptive statistics and logarithm-transformation was performed before group comparisons. The PD20 was described using median and interquartile range and the Mann-Whitney test was used to compare groups [16]. Correlations between continuous numerical data were determined using Pearson's correlation coefficient.

Data were analyzed using the statistics software package Stata (version 12; Stata Corporation, College Station, Texas, USA) and SAS (version 9.4, SAS, Cary, N.C., USA). p-values $\leq 0.05$ were considered significant.

\section{Results}

Of the 408 asthmatic patients included into the study, 200 were males and mean age was $( \pm$ SEM) $20.4 \pm 0.3$ years. Sensitization to peanut and hazelnut was demonstrated in $101(25 \%)$ and in 220 (54\%) subjects, respectively, and sensitization to birch pollen was demonstrated in 228 (56\%) subjects. Ninety-two (91\%) peanut positive subjects were co-sensitized with hazelnut. In total 229 patients were additional tested for peanut and hazelnut related allergen components (Fig. 1, Table 1). Out of these, 215 were birch pollen positives.

In addition to the 74 Ara $h 8$ positive patients among the 101 who were peanut positive, there were another 99

\section{Table 1 Sensitization rates for the studied population $(n=408)$}

\begin{tabular}{ll}
\hline & $\begin{array}{l}\text { Number } \\
\text { of positives } \\
\text { (\%) }\end{array}$ \\
\hline Phadiatop (inhalant allergen mix) & $323(79)$ \\
fx5 (food allergen mix) & $129(32)$ \\
Hazelnut & $220(54)$ \\
Peanut & $101(25)$ \\
Birch & $228(56)$ \\
\hline
\end{tabular}

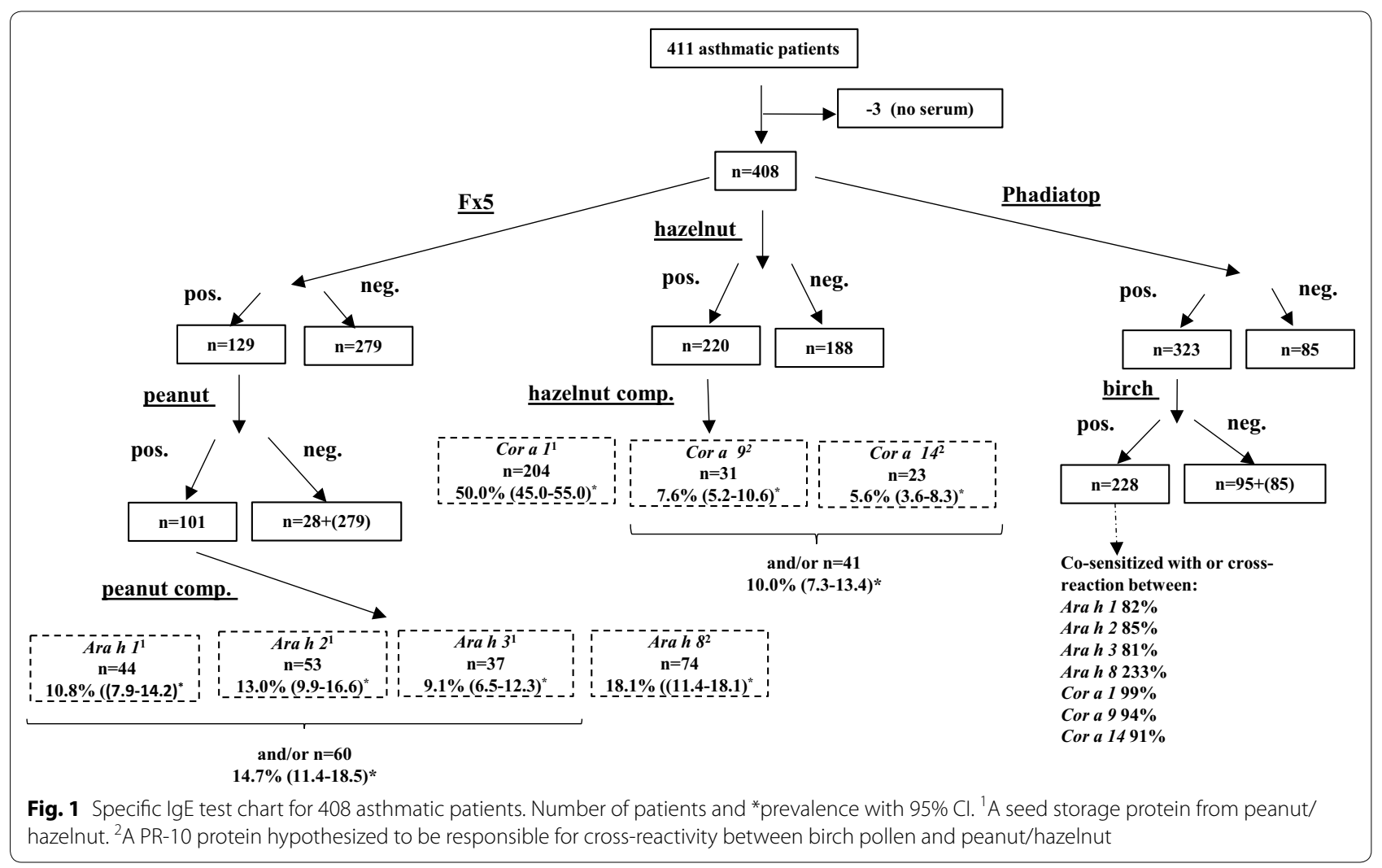


Ara h 8 sensitized patients without IgE antibodies to any of peanut storage proteins, suggesting the absence of primary peanut sensitization $(99 / 215=46 \%)$. The situation for hazelnut sensitization was different. Nearly all hazelnut positives patients were also birch pollen positive. Amongst the birch pollen positive subjects, 183 (85\%) were also positive to at least one of the peanut related allergen components and 206 (96\%) to at least one of the hazelnut related allergen components.

\section{Airway and systemic inflammation markers in relation to allergen component sensitization}

Subjects sensitized to any of Ara h 1, Ara h 2, Ara h 3, Cor a 9 or Cor a 14 were younger and had higher levels of FeNO, B-Eos, S-ECP and total IgE, than other subjects (Table 2, $\mathrm{PH}: 3$ vs $\mathrm{PH}: 1$ ). This group of patients also reported a higher frequency of eczema and they also had increased bronchial responsiveness (lower $\mathrm{PD}_{20}$ ) than patients not sensitized to these seed storage proteins. The findings regarding the levels of FeNO, B-Eos, S-ECP and $\mathrm{PD}_{20}$ persisted after adjustments for age, sex, weight, height, $\mathrm{FEV}_{1}$, current dose of ICS and current smoking (data not shown). However, after further adjustments for presence of aeroallergen sensitization, subjects sensitized to peanut and/or hazelnut storage proteins still had higher levels of FeNO, B-Eos and S-ECP whilst the association to PD20 became statistically non-significant (data not shown).

Table 2 Patient characteristics and inflammation markers in relation to allergen component sensitization $(n=408)$

\begin{tabular}{|c|c|c|c|c|c|c|c|c|c|}
\hline \multirow[b]{2}{*}{ Number (\%) } & \multicolumn{3}{|c|}{$\begin{array}{l}\text { Peanut and Hazelnut in any } \\
\text { combination } \\
\text { PH:1 PH:2 PH:3 }\end{array}$} & \multicolumn{3}{|l|}{$\begin{array}{l}\text { Peanut } \\
\text { P:1 P:2 P:3 }\end{array}$} & \multicolumn{3}{|l|}{$\begin{array}{l}\text { Hazelnut } \\
\mathrm{H:1} \mathrm{H}: 2 \mathrm{H:3}\end{array}$} \\
\hline & $179(44)$ & $156(38)$ & $73(18)$ & $207(51)$ & $141(34)$ & $60(15)$ & $188(46)$ & $179(44)$ & $41(10)$ \\
\hline Age (years) ${ }^{a}$ & $20.9 \pm 0.5$ & $21.2 \pm 0.6$ & $17.6 \pm 0.7^{*, \#}$ & $21 \pm 0.5$ & $21 \pm 0.6$ & $17.2 \pm 0.7^{\mathrm{a}, \#}$ & $20.8 \pm 0.5$ & $20.5 \pm 0.5$ & $17.9 \pm 0.9$ \\
\hline Female $^{b}$ & $95(53)$ & $83(53)$ & $30(41)$ & $107(52)$ & $77(55)$ & $24(40)$ & $101(54)$ & $90(50)$ & $17(41)$ \\
\hline FeNO (ppb)3 & $\begin{array}{l}12.7(11.3- \\
14.2)\end{array}$ & $\begin{array}{c}16.7(14.8- \\
18.7)^{*}\end{array}$ & $\begin{array}{c}23.2(19.6- \\
27.5)^{*, \#}\end{array}$ & $\begin{array}{l}13.1(11.7- \\
14.5)\end{array}$ & $\begin{array}{c}17.3(15.4- \\
19.5)^{d}\end{array}$ & $\begin{array}{c}23.6(19.5- \\
28.5)^{\mathrm{a}, \#}\end{array}$ & $\begin{array}{c}12.8(11.5- \\
14.3)\end{array}$ & $\begin{array}{c}17.7(15.8- \\
19.9)^{\Delta}\end{array}$ & $\begin{array}{l}23.5 \\
\quad(19.1-29)^{\Delta}\end{array}$ \\
\hline FEV1 (\%)1 & $92.9 \pm 1.1$ & $92.2 \pm 1.2$ & $89.6 \pm 1.6$ & $93 \pm 1$ & $91.8 \pm 1.2$ & $89.4 \pm 1.8$ & $92.9 \pm 1$ & $91.9 \pm 1$ & $89 \pm 2.4$ \\
\hline $\begin{array}{l}\text { Methacho- } \\
\text { line ch.test } \\
(\text { PD20 })^{d}\end{array}$ & $0.4(0.1-3)$ & $0.3(0.1-1.8)$ & $0.1(0.1-0.4)^{*}$ & $0.4(0.1-2.9)$ & $0.3(0.1-1.2)$ & $0.1(0-0.1)$ & $0.4(0.1-7.2)$ & $0.3(0.1-1.2)$ & $0.1(0-0.6)$ \\
\hline $\begin{array}{l}\text { Eosinophils } \\
\left(10^{9} / \mathrm{L}\right)^{c}\end{array}$ & $\begin{array}{l}0.15(0.13- \\
0.16)\end{array}$ & $\begin{array}{l}0.17 \\
\quad(0.15-0.2)\end{array}$ & $\begin{array}{c}0.34(0.29- \\
0.41)^{*, \#}\end{array}$ & $\begin{array}{l}0.14(0.13- \\
0.16)\end{array}$ & $\begin{array}{c}0.19(0.17- \\
0.22)^{\mathrm{a}}\end{array}$ & $\begin{array}{c}0.34(0.28- \\
0.41)^{\mathrm{a}, \#}\end{array}$ & $\begin{array}{l}0.15(0.13- \\
0.17)\end{array}$ & $\begin{array}{c}0.19(0.17- \\
0.22)^{\Delta}\end{array}$ & $\begin{array}{c}0.37(0.29- \\
0.46)^{\Delta .}\end{array}$ \\
\hline $\mathrm{ECP}(\mu \mathrm{g} / \mathrm{L})^{\mathrm{c}}$ & $\begin{array}{l}11.6(10.5- \\
12.7)\end{array}$ & $\begin{array}{l}12.4(11.1- \\
13.8)\end{array}$ & $\begin{array}{l}20(17- \\
23.5)^{*, \#}\end{array}$ & $\begin{array}{l}11.6(10.6- \\
12.7)\end{array}$ & $\begin{array}{c}13.2(11.7 \\
-14.9)\end{array}$ & $\begin{array}{c}19.7(16.5- \\
23.5)^{\mathrm{a}, \#}\end{array}$ & $\begin{array}{l}11.7(10.6- \\
12.8)\end{array}$ & $\begin{array}{c}13.1(11.8- \\
14.5)\end{array}$ & $\begin{array}{c}22.1(17.8- \\
27.4)^{\Delta,}\end{array}$ \\
\hline Total lgE (kU/L) & $58(46-73)$ & $\begin{array}{c}213(176- \\
258)^{*}\end{array}$ & $\begin{array}{c}523(396- \\
689)^{*, \#}\end{array}$ & $63(51-78)$ & $\begin{array}{c}265(216- \\
325)^{a}\end{array}$ & $\begin{array}{c}515(378- \\
701)^{\mathrm{a}, \#}\end{array}$ & $62(49-77)$ & $\begin{array}{c}226(190- \\
270)^{\Delta}\end{array}$ & $\begin{array}{c}803(557- \\
1158)^{\Delta,}\end{array}$ \\
\hline Eczema (ever) ${ }^{b}$ & $67(37)$ & $100(64)^{*}$ & $59(81)^{*, \#}$ & $77(37)$ & $101(72)^{a}$ & $48(80)^{a}$ & 73 (39) & $118(66)^{\Delta}$ & $35(85)^{\Delta,}$ \\
\hline $\begin{array}{l}\text { Inh.corticos- } \\
\text { teroids }(\mu \mathrm{g} / \\
\text { day })^{c}\end{array}$ & $\begin{array}{l}404 \\
\quad(369-443)\end{array}$ & $\begin{array}{l}416 \\
\quad(375-461)\end{array}$ & $\begin{array}{l}358 \\
\quad(315-407)\end{array}$ & $\begin{array}{l}400 \\
\quad(369-434)\end{array}$ & $\begin{array}{l}425 \\
(380-475)\end{array}$ & $\begin{array}{l}345 \\
\quad(299-399)\end{array}$ & $\begin{array}{l}404 \\
\quad(370-442)\end{array}$ & $\begin{array}{l}404 \\
\quad(367-444)\end{array}$ & $368(307-442)$ \\
\hline $\begin{array}{l}\text { Birch pollen } \\
\text { sensitization }^{b}\end{array}$ & $13(7)$ & $151(97) *$ & $64(88)^{*, \#}$ & 39 (19) & $137(97)^{x}$ & $52(87)^{\mathrm{a}, \#}$ & $14(7)$ & $176(98)^{\Delta}$ & $38(93)^{\Delta}$ \\
\hline $\begin{array}{l}\text { Ara h } 8 \\
\text { sensitization }^{b}\end{array}$ & & & & - & 132 (94) & $42(70)^{\#}$ & & & \\
\hline $\begin{array}{l}\text { Cor a } 1 \\
\text { sensitization }^{b}\end{array}$ & & & & & & & - & $169(94)$ & $35(85)$ \\
\hline
\end{tabular}

PH:1 not sensitized to peanut or hazelnut; $P H:: 2$ sensitized to peanut and/or Ara h8 and/or hazelnut and/or Cor a 1 but not to any of Ara h 1, 2, 3, Cor a 9, 14; $P H:: 3$ sensitized to peanut and/or Ara h8 and/or hazelnut and/or Cor a and to any of Ara h 1, 2, 3, Cor a 9, 14

$P: 1$ not sensitized to peanut; $P: 2$ sensitized to peanut but not to any of Ara h 1, 2, 3; P:3 sensitized to peanut and to any of Ara h 1, 2, 3

$H: 1$ not sensitized to hazelnut; $H: 2$ sensitized to hazelnut but not to any of Cor a 9, 14; $H: 3$ sensitized to hazelnut and to any of Cor a 9,14

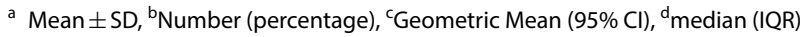

* $\mathrm{p}<0.05$ compared to group $\mathrm{A} 1$

\# $\mathrm{p}<0.05$ compared to group A2

a $p<0.05$ compared to group $B 1$

\#\# $\mathrm{p}<0.05$ compared to group B2

${ }^{\triangle} \mathrm{p}<0.05$ compared to group $\mathrm{C} 1$

$\mathrm{p}<0.05$ compared to group $\mathrm{C2}$ 
Higher levels of FeNO, ECP and B-Eos were found in subjects sensitized to peanut and any of Ara h 1, 2 and 3 as compared to peanut non-sensitized subjects (Table 2, $\mathrm{P}: 3$ vs P:1; Fig. 2). Furthermore, subjects sensitized to peanut, but not to any of Ara h 1, 2 and 3 (Table 2, P:2 vs P:1; Fig. 2) had higher levels of FeNO and B-Eos compared with subjects not sensitized to peanut. Peanut-sensitized subjects without sensitization to Ara h 1, Ara h 2 or Ara h 3 were more frequently sensitized to Ara h 8 and birch pollen than those with sensitization to peanut storage proteins (Fig. 1).

Higher levels of ECP and B-Eos were found in subjects sensitized to hazelnut and any of Cor a 9 and Cor a 14 as compared to hazelnut non-sensitized subjects (Table 2, H:3 vs H:1; Fig. 2). Furthermore, subjects sensitized to hazelnut, but not to Cor a 9 or Cor a 14, had higher levels of FeNO and B-Eos compared with subjects not sensitized to hazelnut (Table 2, H:3 vs H:2; Fig. 2). Hazelnut-sensitized subjects without sensitization to Cor a 9 or Cor a 14 did not differ in frequency of sensitization to Cor a 1 and birch pollen, when compared to those with sensitization to hazelnut storage proteins (Fig. 1).

\section{IgE antibody levels in relation to airway and systemic inflammation markers in children and adults}

Among peanut sensitized subjects, sensitization to any of Ara h 1, Ara h 2 or Ara h 3 was more common in those below 18 years of age (20\% vs. $10 \%$ in adult subjects, $\mathrm{p}<0.001)$. Such a relationship with age was also true for hazelnut-sensitized subjects, where sensitization to any of Cor a 9 or Cor a 14 was more common in subjects younger than 18 years (14\% vs. $7 \%$ in adult subjects, $\mathrm{p}<0.05)$. The frequency of atopy did not differ between children and adults ( $80 \%$ vs. $81 \%)$.

Levels of IgE antibodies to all allergen components except for Ara h 2 and Cor a 1 were higher in children than in adults (Table 3 ).

Among the children, statistically significant correlations were found between levels of FeNO and levels of IgE antibodies against Ara h 1, Ara h 2, Ara h 3, Cor a 9 and Cor a 14, but not against Ara h 8 or Cor a 1 (Table 4). No such correlation between FeNO and IgE antibody levels was found among the adult subjects. Levels of B-Eos correlated with levels of IgE antibodies against all allergen components investigated among the children and with IgE antibodies against the peanut and hazelnut storage proteins among the adults.

\section{Reported food hypersensitivity in relation to allergen component sensitization}

Hypersensitivity symptoms upon peanut intake were more frequently reported among subjects sensitized to any of Ara h 1, Ara h 2 or Ara h 3 than among all other subjects (Table 5, P:3). Hypersensitivity symptoms upon

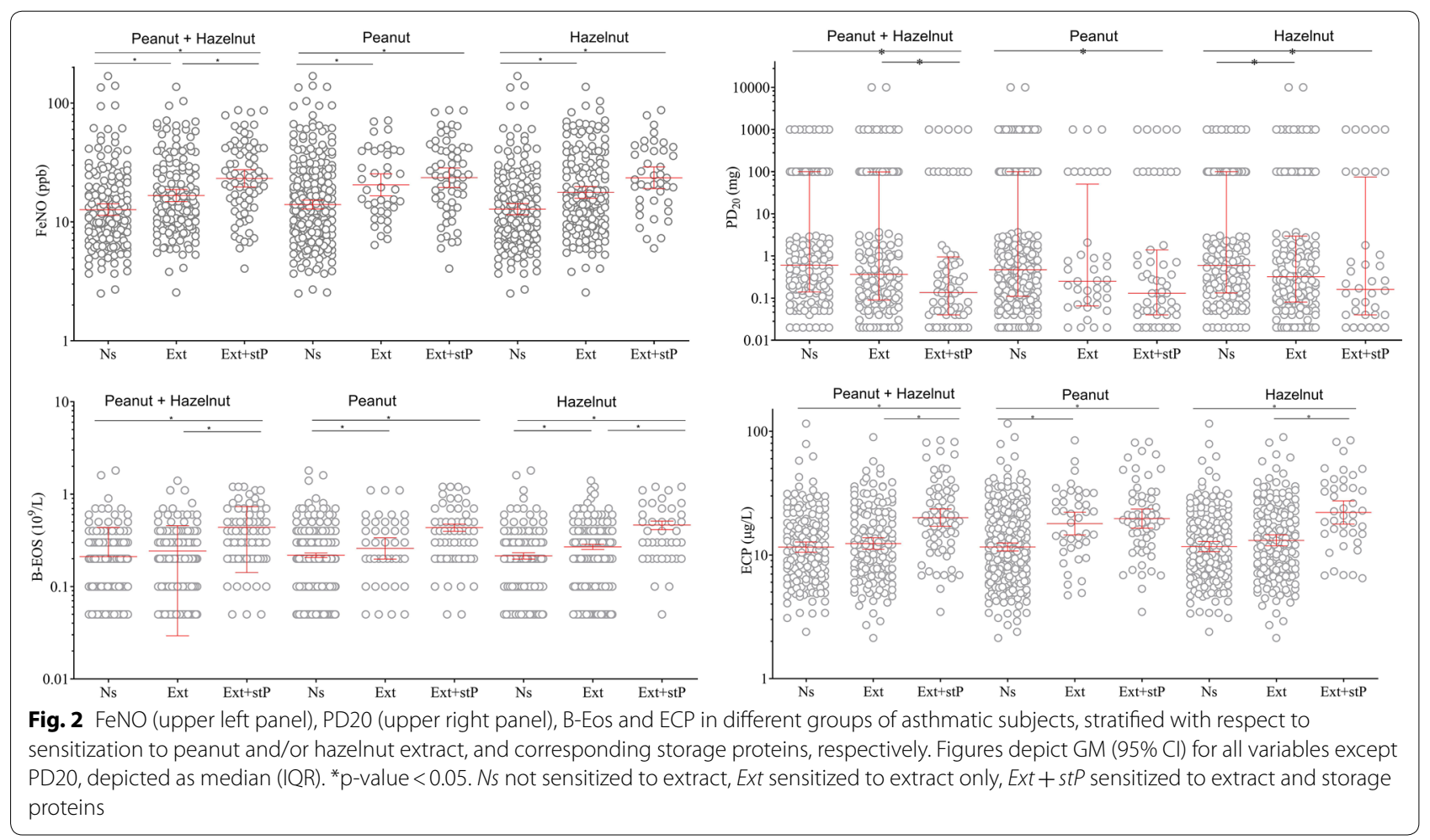


Table 3 Comparison of IgE antibody levels against peanut and hazelnut allergen components between children and adults

\begin{tabular}{llllllll}
\hline & Ara h 1 & Ara h 2 & Ara h 3 & Ara h 8 & Cor 1 & Cor a 9 & Cor a 14 \\
\hline All & $0.13(<0.1-0.18)$ & $0.21(0.12-0.37)$ & $<0.1(<0.1-<0.1)$ & $1.2(0.94-1.6)$ & $4.4(3.4-5.7)$ & $<0.1(<0.1-<0.1)$ & $<0.1(<0.1-<0.1)$ \\
Children & $0.20(0.13-0.33)$ & $0.27(0.12-0.58)$ & $<0.1(<0.1-0.17)$ & $1.9(1.3-2.8)$ & $5.7(3.9-8.3)$ & $0.11(<0.1-0.20)$ & $<0.1(<0.1-0.15)$ \\
Adults & $<0.1(<0.1-0.13)^{* *}$ & $0.15(<0.1-0.35)$ & $<0.1(<0.1-<0.1)^{*}$ & $0.85(0.58-1.3)^{* *}$ & $3.4(2.4-4.9)$ & $<0.1(<0.1-<0.1)^{* *}<0.1(<0.1-<0.1)^{* * *}$ \\
\hline${ }^{*} \mathrm{p}<0.05,{ }^{* *} \mathrm{p}<0.01{ }^{* * *} \mathrm{p}<0.001$ & & & & &
\end{tabular}

Table 4 Correlation between IgE antibody levels and FeNO (A) and B-Eos (B), for all subjects, children and adults

\begin{tabular}{|c|c|c|c|c|c|c|c|}
\hline & Ara h 1 & Ara h 2 & Ara h 3 & Ara h 8 & Cor 1 & Cor a 9 & Cor a 14 \\
\hline \multicolumn{8}{|c|}{ (A) lgE level and FeNO } \\
\hline All subjects & $0.24^{* * *}$ & $0.25^{* * *}$ & $0.27^{* * *}$ & 0.05 & 0.07 & $0.25^{* *}$ & $0.29^{* * *}$ \\
\hline Children & $0.29 * *$ & $0.31^{* *}$ & $0.32^{* * *}$ & 0.03 & 0.05 & $0.27^{* *}$ & $0.36^{* * *}$ \\
\hline Adults & 0.14 & 0.14 & 0.16 & 0.02 & 0.04 & 0.17 & 0.14 \\
\hline \multicolumn{8}{|c|}{ (B) IgE level and B-EOS } \\
\hline All subjects & $0.35^{* * *}$ & $0.38^{* * *}$ & $0.40^{* * *}$ & $0.23^{* * *}$ & $0.19^{* *}$ & $0.34^{* * *}$ & $0.36^{* * *}$ \\
\hline Children & $0.38^{* * *}$ & $0.46^{* * *}$ & $0.50^{* * *}$ & $0.21^{* *}$ & 0.12 & $0.36^{* * *}$ & $0.38^{* * *}$ \\
\hline Adults & $0.25^{* * *}$ & $0.22^{* *}$ & $0.21 *$ & 0.17 & 0.17 & $0.22^{*}$ & $0.22^{*}$ \\
\hline
\end{tabular}

${ }^{*} p<0.05,{ }^{* *} p<0.01,{ }^{* * *} p<0.001$

Table 5 Reported hypersensitivity symptoms and type of symptoms in relation to peanut and hazelnut sensitization profiles

\begin{tabular}{|c|c|c|c|c|c|c|}
\hline & \multicolumn{3}{|c|}{$\begin{array}{l}\text { Peanut }{ }^{\mathrm{a}} \\
\text { P:1 P:2 P:3 }\end{array}$} & \multicolumn{3}{|c|}{$\begin{array}{l}\text { Hazelnut }^{b} \\
\mathrm{H}: 1 \mathrm{H}: 2 \mathrm{H}: 3\end{array}$} \\
\hline & $n=207$ & $n=141$ & $n=60$ & $n=188$ & $n=179$ & $n=41$ \\
\hline No symptoms & $186(90)$ & $87(62)^{*}$ & $2(4)^{*, \#}$ & $160(85)$ & $74(41)^{*}$ & $4(9)^{*, \#}$ \\
\hline Uncertain/never tried peanuts & $4(2)$ & $26(18)^{*}$ & $14(23)^{*}$ & $6(3)$ & $32(18)^{*}$ & $15(37)^{*, \#}$ \\
\hline Yes & $17(8)$ & $28(20)^{*}$ & $44(73)^{*, \#}$ & $22(12)$ & $73(41)^{*}$ & $22(54)^{*}$ \\
\hline Lower airway symptoms & $9(53)$ & $13(46)$ & $31(70)$ & $11(50)$ & $25(34)$ & $11(50)$ \\
\hline Upper airway symptoms & $1(6)$ & $4(14)$ & $5(11)$ & $3(14)$ & $6(8)$ & $2(9)$ \\
\hline Oral cavity symptoms & $11(65)$ & $24(86)$ & $26(59)^{\#}$ & $16(73)$ & $63(86)$ & $19(86)$ \\
\hline Skin symptoms & $2(12)$ & $5(18)$ & $22(50) *, \#$ & $3(14)$ & $17(23)$ & $9(41)^{*}$ \\
\hline Gastrointestinal symptoms & $1(6)$ & $4(14)$ & $12(27)$ & $1(5)$ & $5(7)$ & $10(45)^{*, \#}$ \\
\hline Anaphylaxis & $2(12)$ & $1(4)$ & $10(23)^{\#}$ & $2(9)$ & $2(3)$ & $3(14)^{\#}$ \\
\hline
\end{tabular}

a $P: 1$ not sensitized to peanut; $P: 2$ sensitized to peanut/Ara $\mathrm{h} 8$ but not to any of Ara $\mathrm{h} 1,2,3 ; P: 3$ sensitized to peanut and to any of Ara h 1,2, 3

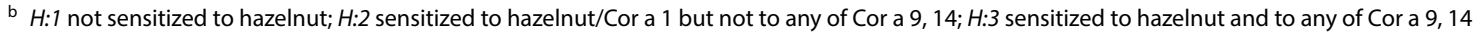

* $\mathrm{p}<0.05$ compared to group P:1 respectively $\mathrm{H}: 1$

\# $\mathrm{p}<0.05$ compared to group $\mathrm{P}: 2$ respectively $\mathrm{H}: 2$

hazelnut intake were more frequently reported among subjects sensitized to hazelnuts, regardless of sensitization to Cor a 9 or Cor a 14, than among those not sensitized to hazelnut (Table 5, H:2, H:3 vs $\mathrm{H}: 1$ ). Those sensitized to Cor a 9 or Cor a 14 were, however, less likely to report absence of symptoms upon hazelnut intake.

Subjects sensitized to any of Ara h 1, Ara h 2 or Ara h 3 more frequently reported skin symptoms upon peanut intake than all other subjects. (Table 5, P:3). The same group also reported a higher frequency of anaphylaxis and a lower frequency of symptoms from the oral cavity than other peanut sensitized subjects. Subjects sensitized to Cor a 9 or Cor a 14 more frequently reported gastrointestinal symptoms upon hazelnut intake than subjects who were sensitized to hazelnut and/or Cor a 1 but not to Cor a 9 or Cor a 14 (Table 5, $\mathrm{H}: 3$ vs $\mathrm{H}: 2$ ). 


\section{Discussion}

In this population of young asthmatics, sensitization to peanut and hazelnut storage proteins was found to be more common in children than in adults and was related both to local and systemic inflammation. Further, a correlation between levels of FeNO and IgE antibodies against peanut and hazelnut storage proteins was observed in children but not in adults.

To our knowledge, this is the first time an asthma cohort consisting of young individuals has been examined regarding patterns of food allergen component sensitization and inflammation markers. We believe that our findings may have clinical implications. In patients sensitized to peanut and hazelnut storage proteins, avoidance of these foods is of importance not only because of the risk of food allergic reactions but also because of an increased risk of respiratory symptoms. A thorough investigation of these asthmatic individuals should be performed, including food challenge if needed. If the peanut sensitization is due to pollen cross-reaction, strict avoidance is not necessary. Thus, one conclusion that can be drawn is that asthmatic patients avoiding nuts due to reactions upon intake should be investigated for sensitization to relevant nut allergen components.

Nut storage proteins, especially the $2 \mathrm{~S}$ albumins, are becoming of increasing interest in nutritional and clinical studies, as they have been reported as major food allergens [29] Although the basis of their allergenic potency is not fully understood, stability to food processing and high resistance against pepsin, trypsin and chymotrypsin digestion are considered to be important factor, in addition to their abundance. Our findings show a correlation between sensitization against storage proteins and inflammatory markers, which further supports the need to identify sensitization to these proteins as indicators of disease processes and an elevated risk of severe allergic reactions. The need of good asthma control in patients with sensitization to these proteins is also emphasized, in particular with respect to the proper use of corticosteroids and other anti-inflammatory treatments.

The reason for stronger signs of inflammation in asthmatic patients with than without sensitization to nut storage proteins is presently unclear. Given that most patients sensitized to the storage proteins are likely to avoid peanuts and tree nuts, it appears unlikely that inflammation is maintained by ongoing subclinical IgEmediated allergic reactions. We propose that this is more likely a bone marrow derived primary cytokine driven phenomenon that in parallel causes both sensitization to strong allergens and signs of Th2-related inflammation [30-32].

The difference between children and young adults regarding the correlation between sensitization and levels of FeNO is an interesting observation. This finding was unexpected and has to our knowledge not previously been described. One possible interpretation is that allergic children in general are both more immunologically active and reactive than allergic adults. Another explanation could be that this is a cohort effect and that the children born in the twenty-first century have more nut allergies compared to an older generation. A third possibility could be tolerance development in the young adults compared to children. Our findings need to be independently corroborated by studies in other patient populations.

Food allergy is related to more severe asthma disease, with an increased risk of exacerbations, a higher rate of corticosteroid use, and more frequent hospitalizations $[21,33]$. Conversely, the prevalence of food allergy appears to be higher among asthmatic subjects than in the general population. It is difficult for the practicing physician to make a risk assessment of an asthmatic patient with suspected peanut or tree nut allergy. The assessment is usually based on symptoms, eliciting dose and a sensitization test based on whole food extract. Dua et al. have shown that exercise and sleep deprivation each significantly reduce the threshold of reactivity in patients with peanut allergy [34]. It seems that estimating the risk of future peanut reaction based on eliciting dose of ingested peanut is difficult. Further, IgE levels of whole allergen such as peanut and hazelnut is difficult to interpret, especially in the presence of birch pollen sensitization due to cross-reactivity between Bet $\mathrm{v} 1$ and homologous food allergens. We are able to show in this study that being sensitized to nut storage proteins is associated with a higher risk of systemic and local inflammation as compared to being sensitized to a Bet v 1 homologue, such as Ara h 8 or Cor a 1 . In order to make an adequate risk assessment, asthma patients experiencing symptoms upon nut intake should therefore be tested for sensitization to relevant nut storage proteins.

There was no association between storage protein sensitization and lower airway symptoms upon peanut or hazelnut intake in our study. This is in contrast to earlier studies, where children sensitized to peanut storage proteins more frequently reported symptoms from the lower airways upon peanut intake than children sensitized only to Ara h 8 [10]. One possible explanation for this is that our study population only included subjects with asthma and that these subjects in general are more likely to report respiratory symptoms from the lower airways. Another explanation could be that these patients are careful regarding the intake of allergenic food such as peanuts and nuts and therefore seldom experience foodinduced respiratory symptoms. 
A strength of our study is the detailed information regarding both asthma morbidity and sensitization patterns in a population known to be at high risk of severe allergic reactions [24]. A limitation of the study is that we lack food challenge data in order to objectively confirming food hypersensitivity. However other studies, such as Andorf et al. have recently shown the associations between Cor a 9 and Cor a 14 sensitization and DBPCFC outcomes [35]. This limitation that we did not perform food challenge in this cohort of asthmatics has been discussed in detail elsewhere [16].

\section{Conclusions}

We conclude that a subgroup of young asthmatic individuals displays sensitization to peanut and hazelnut storage proteins. Storage protein sensitization appears to be associated with asthma morbidity, as this group has higher levels of both local and systemic inflammation markers.

\section{Abbreviations}

B-Eos: Blood eosinophil counts; ECP: Eosinophil cationic protein; FeNO: Fraction of exhaled nitric oxide; $\mathrm{FEV}_{1}$ : Forced expiratory volume in one second; ICS: Inhaled corticosteroids; LTRA: Leukotriene receptor antagonists; MIDAS: Minimally-Invasive Diagnostic procedures in allergy, ASthma, or food hypersensitivity; $\mathrm{PD}_{20}$ : The methacholine provocative dose causing a fall of $\mathrm{FEV}_{1}$ by $20 \%$.
\end{abstract}

\section{Acknowledgements}

We thank all subjects for their participation. We wish to thank the research nurses Pia KalmStephens and Katarina Nisser, as well as the research engineer Britt-Inger Nyberg, for performing the clinical visits and analyses of blood samples.

\section{Authors' contributions}

Conceived and designed the experiments: JJ, AM, LN, CJ, KA. Analyzed the data: JJ, AM, CJP. Contributed reagents/materials/analysis tools: MPB, LN, JL, CJ, KA, AM. Wrote the paper: JJ, AM, JL, CJP, LN, CJ, KA, AM, MPB. All authors read and approved the final manuscript.

\section{Funding}

Andrei Malinovschi had research grants/support from Bror Hjerpstedts Foundation, Uppsala University Hospital and Swedish Heart and Lung Foundation. The MIDAS study was financially supported within the framework of an academy/industry collaboration initiated by the Swedish Governmental Agency for Innovation Systems (VINNOVA, SAMBIO program, grant number 2007-00084), where Aerocrine AB and Thermo Fisher Scientific, Immunodiagnostics were partners and co-financed the program.

\section{Availability of data}

The authors confirm that all data underlying the findings are fully available without restriction. All relevant data are within the paper.

\section{Ethics approval and consent to participate}

The study was approved by the Regional Ethics Committee in Uppsala, Sweden (2009/349). Written informed consent was obtained from each subject and from parents of subjects below 18 years of age, before inclusion in the study.

\section{Consent for publication}

Not applicable.

\section{Competing interests}

JL, CJP and MPB are employed by ThermoFisher Scientific, Uppsala, Sweden. All other authors declare that they have no competing interests.

\section{Author details}

${ }^{1}$ Department of Women's and Children's Health, Uppsala University, Uppsala, Sweden. ${ }^{2}$ Department of Medical Sciences, Clinical Physiology, Uppsala University, Uppsala, Sweden. ${ }^{3}$ Thermo Fisher Scientific, Uppsala, Sweden. ${ }^{4}$ Department of Medical Sciences, Respiratory, Allergy and Sleep Research, Uppsala University, Uppsala, Sweden.

Received: 3 April 2020 Accepted: 16 June 2020

Published online: 23 June 2020

\section{References}

1. Burks W, Sampson HA, Bannon GA. Peanut allergens. Allergy. 1998;53(8):725-30.

2. Borres MP, Ebisawa M, Eigenmann PA. Use of allergen components begins a new era in pediatric allergology. Pediatr Allergy Immunol. 2011;22(5):454-61.

3. Glaumann S, Nopp A, Johansson SG, Rudengren M, Borres MP, Nilsson C. Basophil allergen threshold sensitivity, CD-sens, IgE-sensitization and DBPCFC in peanut-sensitized children. Allergy. 2012;67(2):242-7.

4. Klemans RJ, Liu X, Knulst AC, Knol MJ, Gmelig-Meyling F, Borst E, Pasmans SG, Knol EF. IgE binding to peanut components by four different techniques: ara $\mathrm{h} 2$ is the most relevant in peanut allergic children and adults. Clin Exp Allergy. 2013;43(8):967-74.

5. Koppelman SJ, Wensing M, Ertmann M, Knulst AC, Knol EF. Relevance of Ara h1, Ara h2 and Ara h3 in peanut-allergic patients, as determined by immunoglobulin E Western blotting, basophil-histamine release and intracutaneous testing: ara $\mathrm{h} 2$ is the most important peanut allergen. Clin Exp Allergy. 2004;34(4):583-90.

6. Lieberman JA, Glaumann S, Batelson S, Borres MP, Sampson HA, Nilsson C. The utility of peanut components in the diagnosis of IgE-mediated peanut allergy among distinct populations. J Allergy Clin Immunol Pract. 2013;1(1):75-82.

7. Moverare R, Ahlstedt S, Bengtsson U, Borres MP, van Hage M, Poorafshar M, Sjolander S, Akerstrom J, van Odijk J. Evaluation of IgE antibodies to recombinant peanut allergens in patients with reported reactions to peanut. Int Arch Allergy Immunol. 2011;156(3):282-90.

8. Nicolaou N, Poorafshar M, Murray C, Simpson A, Winell H, Kerry G, Harlin A, Woodcock A, Ahlstedt S, Custovic A. Allergy or tolerance in children sensitized to peanut: prevalence and differentiation using componentresolved diagnostics. J Allergy Clin Immunol. 2010;125(1):191-197.e1-13.

9. Nilsson C, Berthold M, Mascialino B, Orme ME, Sjolander S, Hamilton RG. Accuracy of component-resolved diagnostics in peanut allergy: systematic literature review and meta-analysis. Pediatr Allergy Immunol. 2019. https://doi.org/10.1111/pai.13201.

10. Asarnoj A, Moverare R, Ostblom E, Poorafshar M, Lilja G, Hedlin G, van Hage M, Ahlstedt S, Wickman M. IgE to peanut allergen components: relation to peanut symptoms and pollen sensitization in 8-year-olds. Allergy. 2010;65(9):1189-95.

11. Asarnoj A, Nilsson C, Lidholm J, Glaumann S, Ostblom E, Hedlin G, van Hage M, Lilja G, Wickman M. Peanut component Ara h 8 sensitization and tolerance to peanut. J Allergy Clin Immunol. 2012;130(2):468-72.

12. Beyer K, Grishina G, Bardina L, Grishin A, Sampson HA. Identification of an $11 \mathrm{~S}$ globulin as a major hazelnut food allergen in hazelnut-induced systemic reactions. J Allergy Clin Immunol. 2002;1 10(3):517-23.

13. Flinterman $A E$, Akkerdaas $J H$, Knulst AC, van Ree R, Pasmans SG. Hazelnut allergy: from pollen-associated mild allergy to severe anaphylactic reactions. Curr Opin Allergy Clin Immunol. 2008;8(3):261-5.

14. Masthoff LJ, Mattsson L, Zuidmeer-Jongejan L, Lidholm J, Andersson K, Akkerdaas JH, Versteeg SA, Garino C, Meijer Y, Kentie P, Versluis A, den Hartog Jager C F, Bruijnzeel-Koomen CA, Knulst AC, van Ree R, van Hoffen E, Pasmans SG. Sensitization to Cor a 9 and Cor a 14 is highly specific for a hazelnut allergy with objective symptoms in Dutch children and adults. J Allergy Clin Immunol. 2013;132(2):393-9.

15. Nilsson C, Berthold M, Mascialino B, Orme M, Sjolander S, Hamilton R. Allergen components in diagnosing childhood hazelnut allergy: 
systematic literature review and meta-analysis. Pediatr Allergy Immunol. 2020;31(2):186-96.

16. Johnson J, Borres MP, Nordvall L, Lidholm J, Janson C, Alving K, Malinovschi A. Perceived food hypersensitivity relates to poor asthma control and quality of life in young non-atopic asthmatics. PLOS ONE. 2015;10(4):e0124675.

17. Patelis A, Janson C, Borres MP, Nordvall L, Alving K, Malinovschi A. Aeroallergen and food lgE sensitization and local and systemic inflammation in asthma. Allergy. 2014:69(3):380-7.

18. Kulkarni N, Ragazzo V, Costella S, Piacentini G, Boner A, O'Callaghan C, Fiocchi A, Kantar A. Eosinophilic airway inflammation is increased in children with asthma and food allergies. Pediatr Allergy Immunol. 2012;23(1):28-33.

19. Berns SH, Halm EA, Sampson HA, Sicherer SH, Busse PJ, Wisnivesky JP. Food allergy as a risk factor for asthma morbidity in adults. J Asthma. 2007:44(5):377-81.

20. Liu AH, Jaramillo R, Sicherer SH, Wood RA, Bock SA, Burks AW, Massing $\mathrm{M}$, Cohn RD, Zeldin DC. National prevalence and risk factors for food allergy and relationship to asthma: results from the National Health and Nutrition Examination Survey 2005-2006. J Allergy Clin Immunol. 2010;126(4):798-806.e13.

21. Roberts G, Patel N, Levi-Schaffer F, Habibi P, Lack G. Food allergy as a risk factor for life-threatening asthma in childhood: a case-controlled study. J Allergy Clin Immunol. 2003;112(1):168-74.

22. Simpson AB, Glutting J, Yousef E. Food allergy and asthma morbidity in children. Pediatr Pulmonol. 2007;42(6):489-95.

23. Simpson A B, Yousef E, Hossain J. Association between peanut allergy and asthma morbidity. J Pediatr 2010;156(5):777-81, 781 e1.

24. Bock SA, Munoz-Furlong A, Sampson HA. Fatalities due to anaphylactic reactions to foods. J Allergy Clin Immunol. 2001;107(1):191-3.

25. American Thoracic S, European Respiratory S. ATS/ERS recommendations for standardized procedures for the online and offline measurement of exhaled lower respiratory nitric oxide and nasal nitric oxide, 2005. Am J Respir Crit Care Med. 2005;171(8):912-30.

26. Hagmolen of ten Have W, van den Berg NJ, van der Palen J, Bindels PJ, van Aalderen WM. Validation of a single concentration methacholine inhalation provocation test (SCIPT) in children. J Asthma. 2005;42(6):419-23.
27. Pellegrino R, Viegi G, Brusasco V, Crapo RO, Burgos F, Casaburi R, Coates $A$, van der Grinten CP, Gustafsson P, Hankinson J, Jensen R, Johnson DC, Maclntyre N, McKay R, Miller MR, Navajas D, Pedersen OF, Wanger J. Interpretative strategies for lung function tests. Eur Respir J. 2005;26(5):948-68.

28. Heijkenskjold-Rentzhog C, Nordvall L, Janson C, Borres MP, Alving K, Malinovschi A. Alveolar and exhaled NO in relation to asthma characteristics-effects of correction for axial diffusion. Allergy. 2014;69(8):1102-11.

29. Moreno FJ, Clemente A. $2 \mathrm{~S}$ albumin storage proteins: what makes them food allergens? Open Biochem J. 2008;2:16-28.

30. Bottcher MF, Bjurstrom J, Mai XM, Nilsson L, Jenmalm MC. Allergeninduced cytokine secretion in atopic and non-atopic asthmatic children. Pediatr Allergy Immunol. 2003;14(5):345-50.

31. Tsolakis N, Malinovschi A, Nordvall L, Janson C, Borres MP, Alving K. The absence of serum IgE antibodies indicates non-type 2 disease in young asthmatics. Clin Exp Allergy. 2018;48(6):722-30.

32. Tsolakis N, Malinovschi A, Nordvall L, Mattsson L, Lidholm J, Pedroletti C, Janson C, Borres MP, Alving K. Sensitization to minor cat allergen components is associated with type-2 biomarkers in young asthmatics. Clin Exp Allergy. 2018;48(9):1186-94.

33. Schroeder A, Kumar R, Pongracic JA, Sullivan CL, Caruso DM, Costello J, Meyer KE, Vucic Y, Gupta R, Kim JS, Fuleihan R, Wang X. Food allergy is associated with an increased risk of asthma. Clin Exp Allergy. 2009;39(2):261-70.

34. Dua S, Ruiz-Garcia M, Bond S, Durham SR, Kimber I, Mills C, Roberts G, Skypala I, Wason J, Ewan P, Boyle R, Clark A. Effect of sleep deprivation and exercise on reaction threshold in adults with peanut allergy: a randomized controlled study. J Allergy Clin Immunol. 2019;144(6):1584-1594. e2.

35. Andorf S, Borres MP, Block W, Tupa D, Bollyky JB, Sampath V, Elizur A, Lidholm J, Jones JE, Galli SJ, Chinthrajah RS, Nadeau KC. Association of clinical reactivity with sensitization to allergen components in multifoodallergic children. J Allergy Clin Immunol Pract. 2017;5(5):1325-1334.e4.

\section{Publisher's Note}

Springer Nature remains neutral with regard to jurisdictional claims in published maps and institutional affiliations.
Ready to submit your research? Choose BMC and benefit from:

- fast, convenient online submission

- thorough peer review by experienced researchers in your field

- rapid publication on acceptance

- support for research data, including large and complex data types

- gold Open Access which fosters wider collaboration and increased citations

- maximum visibility for your research: over $100 \mathrm{M}$ website views per year

At BMC, research is always in progress.

Learn more biomedcentral.com/submissions 